Case Reports
in Dermatology
Case Rep Dermatol 2020;12:178-185

DOI: $10.1159 / 000509993$

Published online: October 30, 2020

(C) 2020 The Author(s)

Published by S. Karger AG, Basel

www.karger.com/cde

This article is licensed under the Creative Commons Attribution-NonCommercial 4.0

International License (CC BY-NC) (http://www.karger.com/Services/OpenAccessLicense).

Usage and distribution for commercial purposes requires written permission.

\title{
Trichostasis Spinulosa: A Case Report with an Unusual Presentation
}

\author{
Chaninan Kositkuljorn Poonkiat Suchonwanit \\ Division of Dermatology, Faculty of Medicine, Ramathibodi Hospital, Mahidol University, \\ Bangkok, Thailand
}

\section{Keywords}

Body hair - Dermoscopy · Follicular disorder - Hair disorder - Keratotic papule · Trichoscopy

\section{Abstract}

Trichostasis spinulosa (TS) is a follicular disorder characterized by the retention of multiple vellus hairs in a hyperkeratotic dilated hair follicle. TS is considered as a common disorder; however, it is often underdiagnosed due to its asymptomatic nature. Although the condition frequently affects the face or extremities, the widespread distribution of TS over the entire body has been once reported in a patient with chronic renal failure. To emphasize the infrequent presentation of TS, we herein report a 57-year-old male with an unusual location of TS.

\section{Introduction}

Trichostasis spinulosa (TS) is a disorder of hair follicle characterized by dark, spiny hyperkeratotic follicular papules which commonly locally distribute on the face or extremities [1]. Breast, scalp, lower eyelid, and axillary areas were reported as uncommon affected sites [2-5]. However, extensive involvement of the disease has rarely been reported. 


\section{Case Reports in Dermatology}

Case Rep Dermatol 2020;12:178-185

DOI: 10.1159/000509993

(c) 2020 The Author(s). Published by S. Karger AG, Basel www.karger.com/cde

Kositkuljorn and Suchonwanit: Trichostasis Spinulosa: A Case Report with an Unusual Presentation

\section{Case Report}

A 57-year-old male patient visited an outpatient dermatology clinic for the treatment of chronic eczema. Apart from the chief complaint, numerous dark-brownish keratotic follicular papules were noticed at the entire back without being concerned by the patient (Fig. 1). He reported that the lesions at the back developed since his teenage years without any symptoms. None of his family members had similar lesions. He denied waxing, scrubbing, or applying any topical medications. The dermoscopic examination demonstrated a bundle of short, multiple hairs surrounded by a keratinous sheath in a dilated follicle (Fig. 2).

Skin biopsy was performed at a representative area, which revealed follicular hyperkeratosis with dilated infundibulum containing a group of vellus hair shafts (Fig. 3). Based on the history, clinical presentation, and histopathological findings, the diagnosis was consistent with TS. His treatment comprised twice-daily $10 \%$ urea cream applied on the lesions, and mild improvement was shown at a 4-week follow-up visit.

\section{Discussion}

TS is a follicular disorder characterized by a cluster of short, successive telogen hairs surrounded by keratinous sheath embedded in the same follicular opening. It was first described as "Pinselhaar" (paintbrush hair) by Franke in 1901. Later, Noble introduced the term "trichostasis spinulosa" in 1913 [6]. Clinically, pinhead-sized hyperkeratotic papules are found at the tip of the nose, cheek, extremities, and interscapular area without gender difference. Most of them are asymptomatic, but sometimes they appear to have pruritus, scaling, and erythema. The differential diagnosis of TS includes keratosis pilaris, pili multigemini, and eruptive vellus hair cyst [7-12]. The clinical, dermoscopic, and histopathological features of these diseases are summarized in Table 1.

In 2002, Strobos and Jonkman [13] have proposed two clinical variants of TS including classical variant and pruritic variant. The classical variant manifests with an asymptomatic comedone-like lesion usually located on the face and often seen in the elderly. On the contrary, the pruritic variant, mostly found in adolescence, manifests with multiple itchy follicular papules on the trunk and extremities [13]. However, the proposed classification could not well describe all reported clinical features.

The etiology of this skin disorder remains inconclusive. Some theories believed that the ceased hair shedding by hyperkeratosis of the hair follicle and the abnormal angulation between the isthmus and the infundibulum are the leading causes of TS $[14,15]$. Factors that contribute to follicle damage are congenital dysplasia of the hair follicles and external factors, including ultraviolet light, dust, oils, heat, topical minoxidil, chronic renal failure, Malassezia yeast, Propionibacterium acne, which also have been proposed $[1,9,14,16]$.

In the literature review, an extensive presentation of TS has been once reported in a patient with chronic renal failure who had widespread lesions over the body [14]. This condition disappeared after the patient underwent kidney transplantation. However, the disease recurred within 1 week with the same presentation. Our patient also demonstrated extensive TS with an unusual distribution over the entire back. The overlooked nature of these lesions could be explained by their asymptomatic nature, which leads to an ignorance of the disease. 


\section{Case Reports in Dermatology}

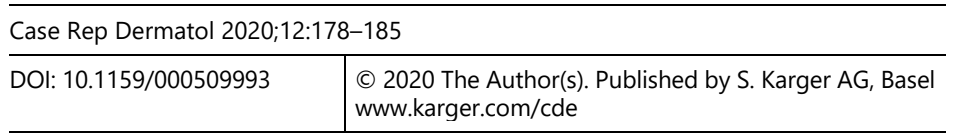

Kositkuljorn and Suchonwanit: Trichostasis Spinulosa: A Case Report with an Unusual Presentation

Several treatment modalities have been reported in the literature, including topical keratolytic agents, emollients, hydroactive adhesive pads, and tretinoin solution; however, their effects are usually temporary $[17,18]$. Other reported treatments include 800 -nm diode laser, which shows $90 \%$ complete clearance of the lesions, short-pulsed 755-nm Alexandrite laser, which can cure all patients in the study without recurrence in 3 months, and long-pulsed 755nm Alexandrite laser, which diminishes more than $50 \%$ of lesions in $51 \%$ of patients [19-21]. Nevertheless, none of these were noted as a curative treatment.

In conclusion, we report a case of TS with an unusual presentation to emphasize to the physicians the need to pay more attention to this common skin disorder. TS may be unrecognized, and most of the cases are discovered incidentally in patients who visit a hospital with other skin conditions. Furthermore, the dermoscopic examination is inexpensive but proven to be an effective method for the diagnosis of TS.

\section{Statement of Ethics}

The patient provided written informed consent to perform all necessary investigations, to take clinical photographs, and use them for research purposes and publication. The patient understood that his name and initial will not be published and due efforts will be made to conceal his identity. This case report was conducted ethically in accordance with the World Medical Association Declaration of Helsinki.

\section{Conflict of Interest Statement}

The authors have no conflicts of interest to declare.

\section{Funding Sources}

The authors have no funding sources to declare.

\section{Author Contributions}

All named authors meet the International Committee of Medical Journal Editors (ICMJE) criteria for authorship for the manuscript, take responsibility for the integrity of the work as a whole, and have given final approval to the version to be published. 


\section{Case Reports in Dermatology}

\section{References}

1 Chung TA, Lee JB, Jang HS, Kwon KS, Oh CK. A clinical, microbiological, and histopathologic study of trichostasis spinulosa. J Dermatol. 1998 Nov;25(11):697-702.

2 Ögretmen Z, Oguz S, Isik S. Trichostasis spinulosa: case report. J Pak Assoc Dermatol. 2013 JulSep;23(3):351-2.

3 Chagas FS, Donati A, Soares II, Valente NS, Romiti R. Trichostasis spinulosa of the scalp mimicking Alopecia areata black dots. An Bras Dermatol. 2014 Jul-Aug;89(4):685-7.

4 Kundu A, Kundu T, Gon S. Trichostasis Spinulosa: An Unusual Diagnosis Presenting as a Double Lower Eyelid. Int J Trichology. 2016 Jan-Mar;8(1):21-3.

5 Ramteke MN, Bhide AA. Trichostasis Spinulosa at an Unusual Site. Int J Trichology. 2016 Apr-Jun;8(2):78-80.

6 Naveen KN, Shetty SR. Trichostasis spinulosa: an overlooked entity. Indian Dermatol Online J. 2014 Dec;5(6 Suppl 2):S132-3.

7 Alfaro-Castellón P, Mejía-Rodríguez SA, Valencia-Herrera A, Ramírez S, Mena-Cedillos C. Dermoscopy distinction of eruptive vellus hair cysts with molluscum contagiosum and acne lesions. Pediatr Dermatol. 2012 Nov-Dec;29(6):772-3.

8 Ciudad-Blanco C, Montero EC, Heffernan JA, Ochaita PL. Extensive pili multigemini over the back. Int J Trichology. 2014 Oct;6(4):180-1.

9 Panchaprateep R, Tanus A, Tosti A. Clinical, dermoscopic, and histopathologic features of body hair disorders. J Am Acad Dermatol. 2015 May;72(5):890-900.

10 Tosti A, Tosti A. Dermoscopy of the hair and nails. Second edition. Boca Raton: CRC Press; 2016.

11 Jerdan K, St Claire K, Bain M. Eruptive vellus hair cysts in identical triplets with dermoscopic findings. Cutis. 2018 Nov;102(5):367-9.

12 Sonthalia S, Bhatia J, Thomas M. Dermoscopy of Keratosis Pilaris. Indian Dermatol Online J. 2019 Aug;10(5):613-4.

13 Strobos MA, Jonkman MF. Trichostasis spinulosa: itchy follicular papules in young adults. Int J Dermatol. 2002 Oct; $41(10): 643-6$.

14 Sidwell RU, Francis N, Bunker CB. Diffuse trichostasis spinulosa in chronic renal failure. Clin Exp Dermatol. 2006 Jan;31(1):86-8.

15 Kelati A, Aqil N, Mernissi FZ. Dermoscopic Findings and Their Therapeutic Implications in Trichostasis Spinulosa: A Retrospective Study of 306 Patients. Skin Appendage Disord. 2018 Oct;4(4):291-5.

16 Navarini AA, Ziegler M, Kolm I, Weibel L, Huber C, Trüeb RM. Minoxidil-induced trichostasis spinulosa of terminal hair. Arch Dermatol. 2010 Dec;146(12):1434-5.

17 Mills OH Jr, Kligman AM. Topically applied tretinoin in the treatment of trichostasis spinulosa. Arch Dermatol. 1973 Sep;108(3):378-80.

18 Elston DM, White LC. Treatment of trichostasis spinulosa with a hydroactive adhesive pad. Cutis. 2000 Jul;66(1):77-8.

19 Toosi S, Ehsani AH, Noormohammadpoor P, Esmaili N, Mirshams-Shahshahani M, Moineddin F. Treatment of trichostasis spinulosa with a 755-nm long-pulsed alexandrite laser. J Eur Acad Dermatol Venereol. 2010 Apr;24(4):470-3.

20 Badawi A, Kashmar M. Treatment of trichostasis spinulosa with 0.5-millisecond pulsed 755-nm alexandrite laser. Lasers Med Sci. 2011 Nov;26(6):825-9.

21 Chavan DK, Chavan DD, Nikam BP, Kale MS, Jamale VP, Chavan SD. Efficacy of $800 \mathrm{~nm}$ Diode Laser to Treat Trichostasis Spinulosa in Asian Patients. Int J Trichology. 2018 Jan-Feb;10(1):21-3. 
Case Reports
in Dermatology

Case Rep Dermatol 2020;12:178-185

DOI: 10.1159/000509993

(C) 2020 The Author(s). Published by S. Karger AG, Basel

Kositkuljorn and Suchonwanit: Trichostasis Spinulosa: A Case Report with an Unusual

Presentation

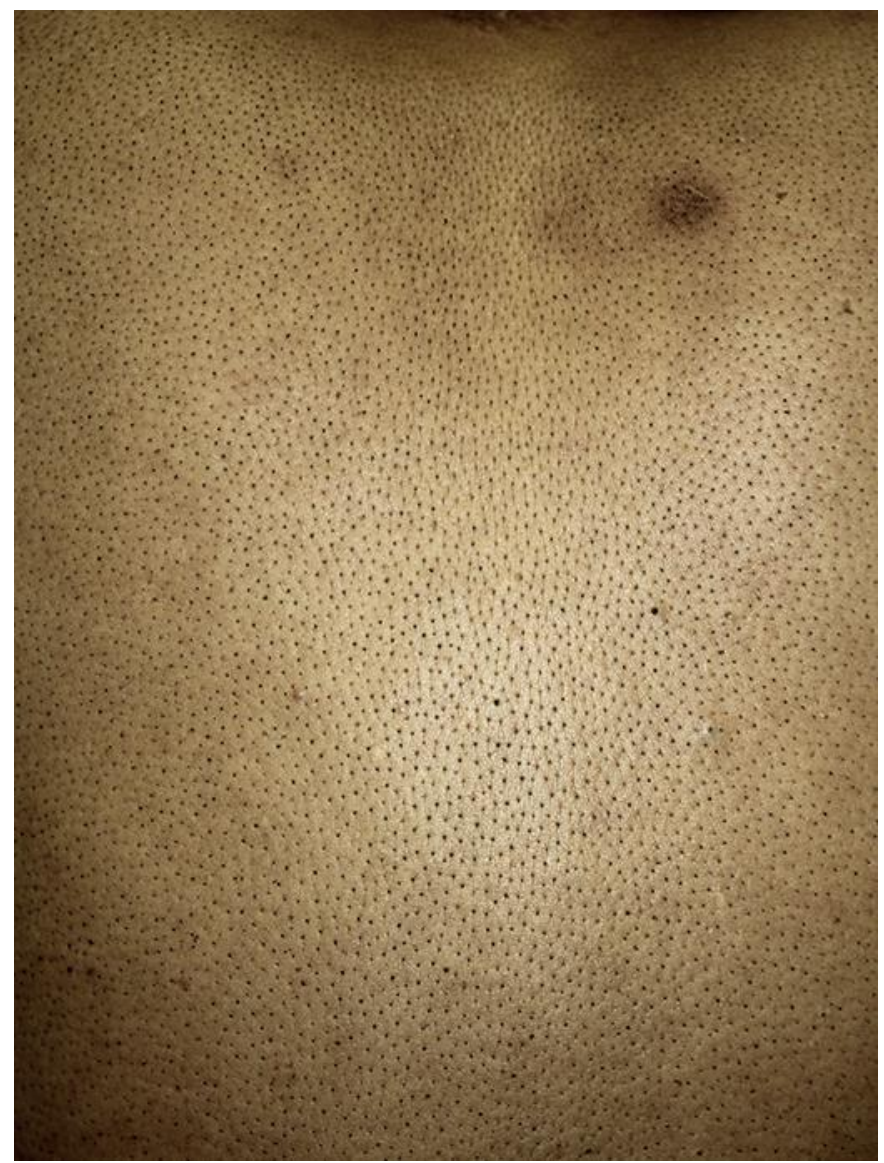

Fig. 1. Extensive diffuse dark-brown keratotic follicular papules at the entire back. 
Case Reports
in Dermatology

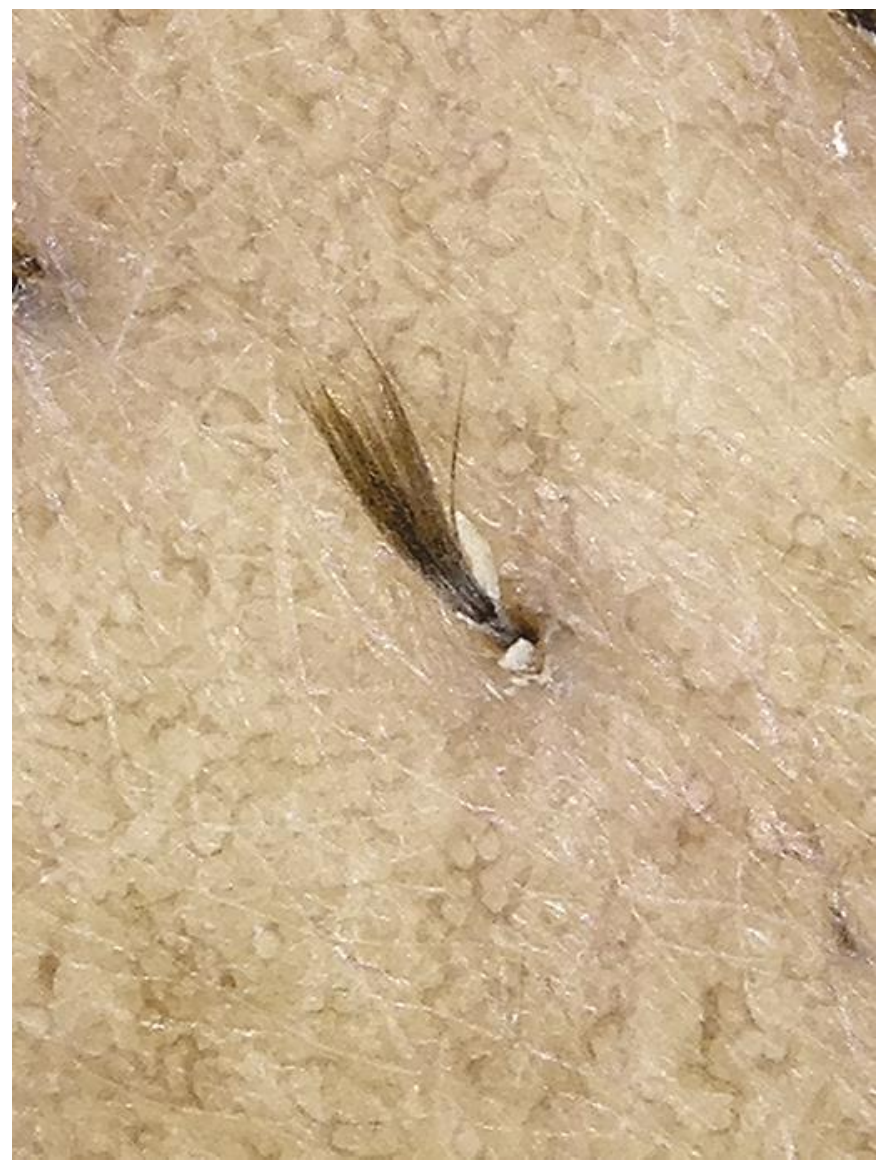

Fig. 2. Dermoscopic examination shows a bundle of short, multiple hairs surrounded by a keratinous sheath in a dilated follicle. 


\section{Case Reports in Dermatology}

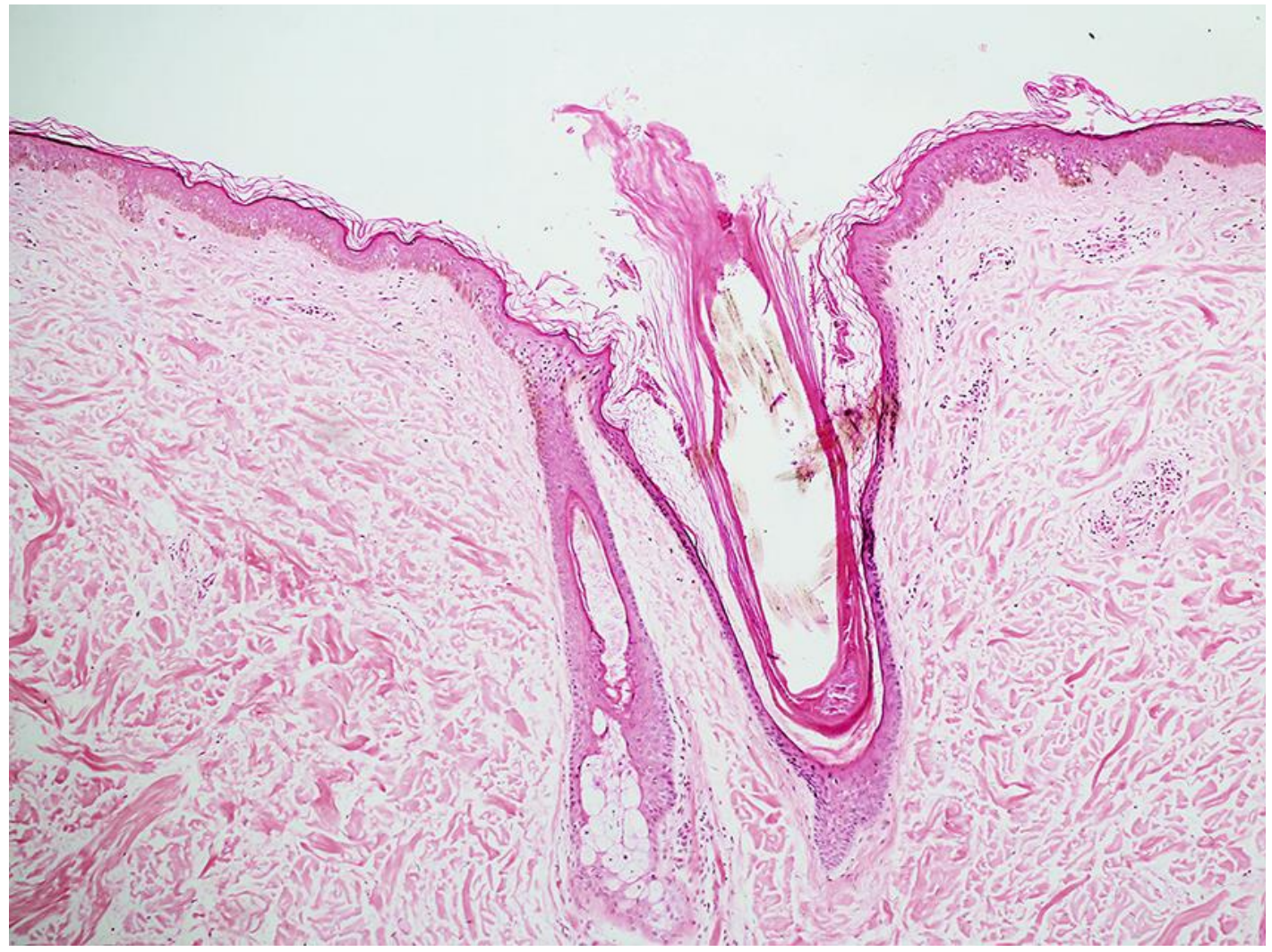

Fig. 3. Histopathological features show hyperkeratosis with follicular plugging, widening of the hair follicle with numerous vellus hairs enveloped in a keratinous sheath. Hematoxylin-eosin stain. Original magnification, $\times 10$. 


\section{Case Reports in Dermatology}

\begin{tabular}{l|l}
\hline Case Rep Dermatol 2020;12:178-185 \\
\hline DOI: 10.1159/000509993 & $\begin{array}{l}\text { (c) 2020 The Author(s). Published by S. Karger AG, Basel } \\
\text { www.karger.com/cde }\end{array}$ \\
\hline
\end{tabular}

Kositkuljorn and Suchonwanit: Trichostasis Spinulosa: A Case Report with an Unusual Presentation

Table 1. Clinical, dermoscopic, and histopathological features in trichostasis spinulosa, keratosis pilaris, pili multigemini, and eruptive vellus hair cyst

\begin{tabular}{|c|c|c|c|}
\hline & Clinical characteristics & Dermoscopic features & Histopathological features \\
\hline $\begin{array}{l}\text { Trichostasis } \\
\text { spinulosa }\end{array}$ & $\begin{array}{l}\text { Horny, spinous plug or dark-brown follic- } \\
\text { ular papules; common site: face, trunk, } \\
\text { and extremities }\end{array}$ & $\begin{array}{l}\text { Retention of vellus hairs embed- } \\
\text { ded in keratinous sheath in a di- } \\
\text { late follicular opening }\end{array}$ & $\begin{array}{l}\text { Dilated hair follicle containing nu- } \\
\text { merous vellus hairs surrounded by } \\
\text { hyperkeratinous sheath }\end{array}$ \\
\hline Pili multigemini & $\begin{array}{l}\text { Hyperpigmented papules with short and } \\
\text { irregular hairs; common site: beard of } \\
\text { men and scalp of children }\end{array}$ & $\begin{array}{l}\text { Cluster of short hair shafts emerg- } \\
\text { ing from one hair follicle }\end{array}$ & $\begin{array}{l}\text { Bunch of hair shafts with separate } \\
\text { inner route sheath enclosed in one } \\
\text { common outer route sheath }\end{array}$ \\
\hline Keratosis pilaris & $\begin{array}{l}\text { Folliculocentric keratotic papules, resem- } \\
\text { bling gooseflesh appearance, with peri- } \\
\text { follicular erythema and coiled, brittle hair; } \\
\text { common site: extensor part of arms, thigh, } \\
\text { and buttock }\end{array}$ & $\begin{array}{l}\text { Loop and coiled vellus hairs em- } \\
\text { bedded in epidermis with peri- } \\
\text { follicular erythema and hyperpig- } \\
\text { mentation }\end{array}$ & $\begin{array}{l}\text { Follicular hyperkeratosis, plugging, } \\
\text { and perifollicular inflammation; } \\
\text { the dilated hair follicle contains } \\
\text { coiled vellus hairs }\end{array}$ \\
\hline $\begin{array}{l}\text { Eruptive vellus hair } \\
\text { cyst }\end{array}$ & $\begin{array}{l}\text { A symptomatic skin-color to hyperpig- } \\
\text { mented papules with smooth or centrally } \\
\text { umbilicated surface; common site: chest } \\
\text { and extremities }\end{array}$ & $\begin{array}{l}\text { Yellowish homogeneous circular } \\
\text { structures with erythematous } \\
\text { halo with central grey-blue color } \\
\text { point }\end{array}$ & $\begin{array}{l}\text { Stratified squamous epithelium- } \\
\text { lined cyst containing multiple vel- } \\
\text { lus hairs and keratinous matrix }\end{array}$ \\
\hline
\end{tabular}

